\title{
Notes on Pleuroxus (Picripleuroxus) quasidenticulatus (Smirnov, 1996) (Cladocera: Anomopoda: Chydoridae) from South-East Asia and the East of Russia
}

\author{
Artem Yu. Sinev ${ }^{1}$, La-orsri Sanoamuang ${ }^{2}$ \\ ${ }^{I}$ Department of Invertebrate Zoology, Biological Faculty, M.V. Lomonosov Moscow State Univer- \\ sity, Leninskie Gory, Moscow, 119991,Russia.e-mail: artemsinev@yandex.ru \\ 2 Applied Taxonomic Research Center, Department of Biology, Faculty of Science, Khon Kaen \\ University, Khon Kaen 40002, Thailand.e-mail: la_orsri@kku.ac.th
}

ABSTRACT: The morphology of the Australasian Pleuroxus (Picripleuroxus) quasidenticulatus (Smirnov, 1996) (Cladocera: Anomopoda: Chydoridae) was studied, using material from Thailand, Vietnam and the Far East of Russia. The morphology of the thoracic limbs and the detailed morphology of males were studied for the first time. The taxonomic position, relationship and distribution of the species are discussed. The species is recorded for Russia for the first time and this is one of the few tropical cladoceran species penetrating this far North.

How to cite this article: Sinev A.Yu., Sanoamuang L. 2013. Notes on Pleuroxus (Picripleuroxus) quasidenticulatus (Smirnov, 1996) (Cladocera: Anomopoda: Chydoridae) from South-East Asia and the East of Russia // Invert. Zool. Vol.10. No.2. P.269-280.

KEY WORDS: Cladocera, Pleuroxus, morphology, systematics, distribution, East Asia.

\section{Заметки о Pleuroxus (Picripleuroxus) quasidenticulatus (Smirnov, 1996) (Cladocera: Anomopoda: Chydoridae) из Юго-Восточной Азии и с Дальнего Востока России}

\footnotetext{
А.Ю. Синев ${ }^{1}$, Л. Саноамуанг ${ }^{2}$

${ }^{1}$ Кафедра зоологии беспозвоночных, Биологический Факультет Московсткого Государственного Университета им. М.В. Ломоносова, Ленинские Горы, Москва 119991, Росиия. Еmail: artemsinev@yandex.ru

${ }^{2}$ Applied Taxonomic Research Center, Department of Biology, Faculty of Science, Khon Kaen University, Khon Kaen 40002, Thailand.E-mail: la_orsri@kku.ac.th

РЕЗЮМЕ: Морфология австралазийского ветвистоусого ракообразного Pleuroxus (Picripleuroxus) quasidenticulatus (Smirnov, 1996)(Cladocera: Anomopoda: Chydoridae) была исследована по материалу из Таиланда, Вьетнама и Дальнего Востока России. Впервые приводится описание строение торакальных конечностей и подробное описание морфологии самца этого вида. Обсуждается систематическое положение, родственные связи и распространение вида. Вид впервые отмечен для России: это один из немногих “тропических” видов кладоцер, проникающих настолько далеко на север.
} 
Как цитировать эту статью: Sinev A.Yu., Sanoamuang L. 2013. Notes on Pleuroxus (Picripleuroxus) quasidenticulatus (Smirnov, 1996)(Cladocera: Anomopoda: Chydoridae) from South-East Asia and the East of Russia // Invert. Zool. Vol.10. No.2. P.269-280.

КЛЮЧЕВЫЕ СЛОВА: Cladocera, Pleuroxus, морфология, систематика, распространение, Восточная Азия.

\section{Introduction}

The subgenus Picripleuroxus Frey, 1993 was a one of four subgenera of Pleuroxus Baird, 1843 proposed by Frey (1993) for the Pleuroxus laevis Sars, 1862 group. Unlike two other subgenera, Tylopleuroxus Frey, 1993 and Peracantha Frey, 1993, Picripleuroxus was later recognized as a genus by Smirnov (1996), but such a disposition has been challenged in recent works (Chiambeng, Dumont, 2004; Smirnov et al., 2006). According to Smirnov (1996), the group includes seven species. Three of them, the Palaearctic $P$. laevis, Nearctic $P$. straminius (Birge, 1870) and Nearctic P. chiangi Frey, 1988, were thoughtfully revised by Frey (1988) and their descriptions and redescriptions are among the best ones for the Chydoridae. But the general situation with the taxonomy of this group is far from clear.

Investigations of $P$. denticulatus (Birge, 1879) revealed at least two sibling species in North America (Shan, Frey, 1983; Hudec, Illyová, 1998; Sinev, Zawisza, 2013). The status of European populations, presumed to be recently introduced from North America, is not clear (Hudec, Illyova, 1998). The Holarctic $P$. striatus Schoedler, 1863 was also recorded from Africa (Smirnov, 1996). The situation with tropical populations of Picripleuroxus is especially confusing $-P$. similis Vavrá, 1900 was recorded from South America and Central Asia (Smirnov 1996), P. quasidenticulatus Smirnov, 1996 - from Australia (where type locality is located), Iraq and Argentina (Smirnov 1996), Thailand (Maiphae et al., 2008) and Vietnam (Sinev, Korovchinsky, 2013). While the absence of Palaearctic P. laevis s.str. in North America was proven by Frey (1988), this taxon was reported from Africa and Central Asia (Smirnov, 1971), India, China and Indochina (Chiang, Du, 1979; Idris, 1983; Sharma, Michael, 1987; Maiphae et al., 2008), and Australia (Smirnov, 1996). Such a broad distribution typ- ically suggest a presence of a complex of crypic species (Frey, 1995). The Chinese P. sinkiangensis Chiang, 1964 was presumed to be a synonym of $P$. laevis by Smirnov (1996), but, according to the initial description (Chiang, 1964), this species has an acute denticle on postero-ventral corner of the valves, instead of the blunt one characteristic of European $P$. laevis s.str. (see Frey, 1998; Sinev, Korovchinsky, 2013).

Recent investigations of the $P$. aduncusgroup of Pleuroxus (Tylopleuroxus) (Smirnov et al., 2006; Kotov, Sheveleva, 2008) reveals its rather complex structure, with several endemic species confined to limited areas, especially mountain ranges. Sibling species with similar parthenogenetic females, which can be distinguished predominantly based on the morphology of the males or ephippial females, frequently found among Chydoridae (Kubersky, 1977; Frey, 1985; Belyaeva, Taylor, 2009). A separation of $P$. chiangi from $P$. laevis also became possible only after detailed study of the gamogenetic stages, especially males (Frey, 1988).

The taxonomic status of Pleuroxus (Picripleuroxus) taxa from South-East and East Asia remains unclear so far. According to Idris (1983), only P. laevis is present in Malaysia. Two species, $P$. laevis and $P$. quasidenticulatus, were recorded in Thailand (Maiphae et al., 2008). Sinev and Korovchinsky (2013) reported two species from Vietnam, $P$. sinkiankensis (instead of the previous reports of $P$. laevis) and $P$. quasidenticulatus. The detailed morphology of $P$. quasidenticulatus has remained unknown so far, the outer morphology was briefly described by Smirnov (1996) for different populations and then by Sinev, Korovchinsky (2013) for Vietnamese populations. Chiang, Du (1979) list P. laevis, P. sinkiankensis and $P$. striatus for China, and a record of $P$. assimilis Brady 1907 (Chiang, Du, 1979) also belongs to $P$. quasidenticulatus (Sinev, Korovchinsky, 2013). Recently, P. cf. den- 
ticulatus was recorded from Zeya River Basin, Far East of Russia (Kotov et al., 2011), and probably this record also belongs to $P$. quasidenticulatus.

The aim of the present manuscript was to study the detailed morphology of $P$. quasidenticulatus from Thailand and Vietnam and compare it with that of populations from the Far East of Russia.

\section{Materials and methods}

The study is based on samples collected in Thailand, Vietnam and the Far East of Russia. Adult males of $P$. quasidenticulatus from Thailand were obtained by hormonal induction with methylfarnesoate in short-term multispecies cultures. Hormonal induction of males was first used in taxonomy of bosminids and daphniids (Kim et al., 2006). For the detailed description of the methodology in our case see Sinev, Sanoamuang (2011), the species listed there as Pleuroxus sp.

Animals and exuviae were selected from wet samples under a binocular stereoscopic microscope, placed on slides (in a drop of a glycerol-ethanol mixture), and studied under an optical microscope in toto (and measured). One to five specimens from each population were dissected for study of the appendages. For SEM examination; specimens were submitted to critical point drying, coated with goldpalladium, and studied under a scanning electron microscope (JEOL 405-A). Measurements were conducted using an eyepiece-micrometer; all drawings were made with a camera lucida.

\section{Results}

Our data confirms the identity of the studied populations as P. (Picripleuroxus) quasidenticulatus. Morphology of thoracic limbs and morphology of males of this species are described for the first time.

\section{Taxonomy}

\section{Order Anomopoda Sars, 1865}

Family Chydoridae Dybowski et Grochowski, 1894 emend. Frey, 1967
Subfamily Chydorinae Dybowski et Grochowski, 1894 emend. Frey, 1967

Genus Pleuroxus Baird, 1843 1993

Subgenus Pleuroxus (Picripleuroxus) Frey,

Pleuroxus (Picripleuroxus) quasidenticulatus (Smirnov, 1996)

Smirnov, 1996: 31, Figs. 79-102.

Material studied. Over 40 parthenogenetic $\circ \circ, 2$ adult $\sigma^{7} \sigma^{7}$ from Thailand, Khon Kaen area, Loeng Yai reservoir, $16^{\circ} 26^{\prime} 51^{\prime \prime} \mathrm{N}, 102^{\circ} 58^{\prime} 00^{\prime \prime} \mathrm{E}$, coll. A.Y. Sinev ( $\sigma^{\top} \sigma^{\top}$ are obtained in culture); 7 parthenogenetic 우 from Vietnam, Dong Nai province, Cat Tien National park, small forest lake near Bau Sau lake, N 11 ${ }^{\circ} 27.178^{\prime}$, E $107^{\circ} 20.328,05.2009$, coll. A.Y. Sinev; 16 parthenogenetic $+\circ$ from the same location, 10.2010, coll. A.Y. Sinev; 3 \$ from Vietnam, Dong Nai province, Cat Tien National park, Cat Tien National park, small forest stream, $\mathrm{N} 11^{\circ}$ 26.250', E $107^{\circ} 25.621^{\prime} ; 10.2010$, coll. A.Y. Sinev; 3 parthenogenetic $\circ$ + from Vietnam, Dong Nai province, Ta Lai village near Cat Tien National park, small village pond with lotus, N $11^{\circ} 22.253^{\prime}$, E $107^{\circ} 21.386^{\prime}, 10.2010$, coll. A.Y. Sinev; 17 parthenogenetic $\circ \circ, 5$ ephippial 90,3 adult $\sigma^{\top} \sigma^{\top}, 1$ juvenile $\sigma^{7}$ of instar II from Russia, Primorsky Area, Nakhodka District, Nakhodka, Primorskoe Lake, 29.09.2004, coll. A.Y. Sinev; 7 parthenogenetic 90 from Russia, Primorsky Area, Nakhodka District, ditch in Avangard village, 25.09.2004, coll. A.Y. Sinev; 5 parthenogenetic 90 from Russia, Primorsky Area, Nakhodka District, small lake near Avangard village, 27.09.2004, coll. A.Y. Sinev.

Description. Parthenogenetic female. Body of preserved specimens from yellow-brownish to colorless, relatively opaque. In lateral view body oval, low in juveniles (Fig. 1A), of moderate height in adult (Figs. 1B, 2A-B) (height/ length ratio $0.72-0.80$, increasing with the size of specimen), maximum height slightly before midline. Body moderately compressed laterally (Fig. 2C). Dorsal margin evenly arched from tip of rostrum to postero-dorsal angle, which is weakly defined, posterior margin weakly convex, postero-ventral angle well-defined, with 1-3 denticles. Ventral margin convex in anterior half, almost straight in posterior half. Anterior corner of valves broadly rounded, with a distinctive marginal rim. Valves with a distinct reticulation in antero-ventral part only, and a fine punctuation in dorsal portion. Ventral margin (Fig. 2D-E) armed with numerous (about 70) setae of different size in different regions, in anterior portion they are shorter and armed with short setules. In posterior part of margin, 


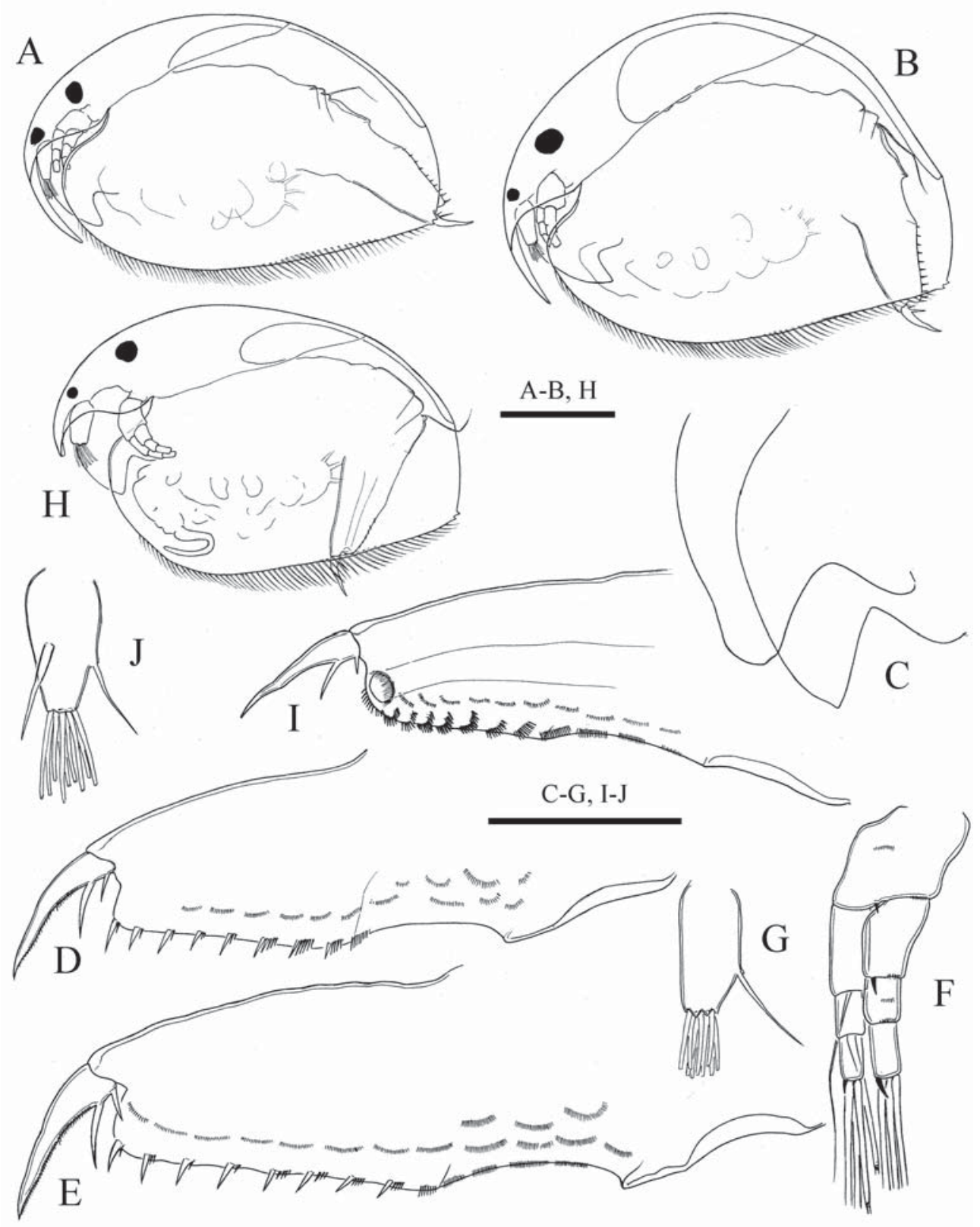

Fig. 1. Picripleuroxus quasidenticulatus (Smirnov, 1996) from Thailand, Khon Kaen area, Loeng Yai reservoir.

A - juvenile female of instar II; B-G - parthenogenetic female: B - lateral view, C - contour of labrum, D-E postabdomen, $\mathrm{F}$ - antenna, $\mathrm{G}$ - antennule; $\mathrm{H}-\mathrm{J}$ - adult male: $\mathrm{H}$ - lateral view, I - postabdomen, $\mathrm{J}$ - antennule. Scale bars A-B, H-0.1 mm; C-G, I-J $-0.05 \mathrm{~mm}$.

Рис. 1. Picripleuroxus quasidenticulatus (Smirnov, 1996) из Таиланда, окрестности Кхон Кена, водохранилище Loeng Yai.

A - ювенильная самка второго возраста; B-G - партеногенетическая самка: В - вид сбоку, C - контуры верхней губы, D-E - постабдомен, F - антенна, G - антеннула; H-J - самец: Н - вид сбоку, I- постабдомен, J - антеннула. Масштаб А-B, H-0,1 мм; C-G, I-J - 0,05 мм. 


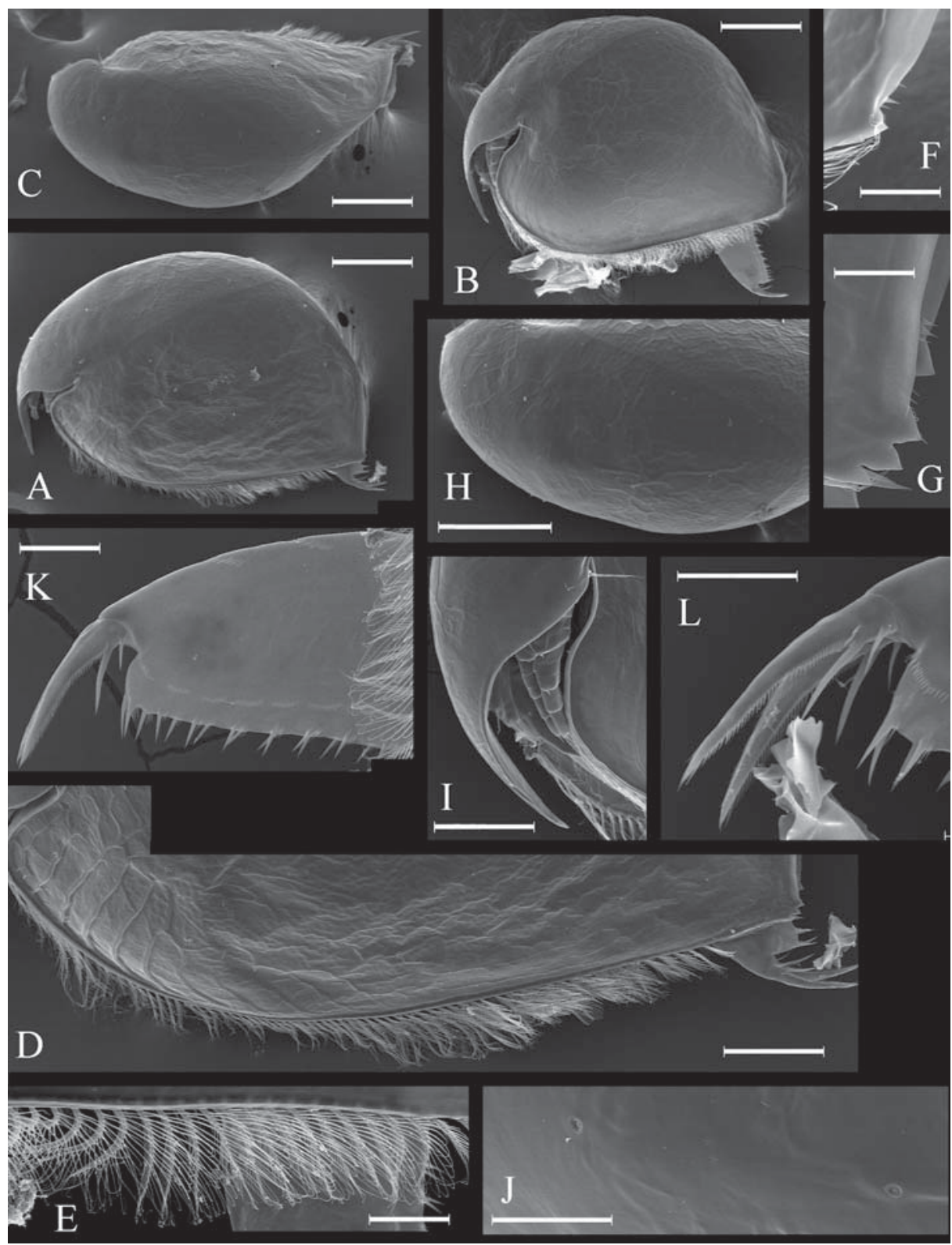

Fig. 2. Picripleuroxus quasidenticulatus (Smirnov, 1996) from Thailand, Khon Kaen area, Loeng Yai reservoir, parthenogenetic females.

A-B - lateral view; C - dorsal view; D - ventral margin of valves; $\mathrm{E}$ - setae of ventral margin of valves; $\mathrm{F}-\mathrm{G}$ denticles of postero-ventral corner of valves; $\mathrm{H}$ - head shield; I - rostrum and antenna; J - head pores; $\mathrm{K}$ postabdomen; L - postabdominal claw. Scale bars A-C, H-0.1 mm; D, I $-0.05 \mathrm{~mm} ; \mathrm{J}, \mathrm{K}-0.02 \mathrm{~mm}$; E-G -0.01 $\mathrm{mm}$.

Рис. 2. Picripleuroxus quasidenticulatus (Smirnov, 1996) из Таиланда, окрестности Кхон Кена, водохранилище Loeng Yai, партеногенетическая самка.

A-B - вид сбоку; С - вид со спины; D - брюшной край створок; Е - щетинки брюшного края створокs; $\mathrm{F}-$ $\mathrm{G}$ - зубцы задне-нижнего угла створок; $\mathrm{H}$ - головной щит; I — рострум и антенна; J — головные поры; $\mathrm{K}$ постабдомен; L - когти постабдомена. Масштаб A-C, H- 0,1 мм; D, I- 0,05 мм; J, K-0,02 мм; E-G - 0,01 MM. 
setae are long, armed with very long setules. Denticles on the postero-ventral corner of valves (Fig. 2E-F, 3A) with broad bases, relatively short, width of base of the denticle exceeds its length. Several robust, irregularly spaced setules located on posterior margin of valves near the denticles.

Head (Fig. 2I) with a long rostrum, protruding downward and posterior, length of rostrum about 2.5-3 length of antennules. Ocellus 2-3 times smaller than eye. Head shield elongated, with maximum width after mandibular articulation, its posteriormost portion oval (Fig. $2 \mathrm{H}$ ). Two major head pores (Fig. 2J), postpore distance $=$ about 3 interpore distance. Lateral head pores minute, normally located asymmetrically, close to midline.

Labrum (Fig. 1C) with fleshy main body, small distal labral plate and a large medial labral keel, projecting almost to the level of rostrum tip. Labral keel narrow, with acute to rounded apex. Anterior margin of keel convex, posterior margin almost straight.

Thorax three times longer than abdomen. Dorsal surface of abdominal segments not saddle-shaped. Abdominal joint not developed.

Postabdomen (Fig. 1D-E, 2K, 3B) moderately long, narrowing distally, with maximum height at postanal angle. Length about 3.5-4 heights. Ventral margin weakly convex. Basis of claws bordered from distal margin by clear incision. Distal margin from almost straight to weakly convex, distal angle rounded, prominent. Dorsal margin straight to weakly concave in postanal portion and concave in the anal one, with distal part about 2.5-3 times longer than the preanal portion.Postanal portion 2.52.8 times longer than anal portion. Preanal angle well expressed, prominent, postanal angle weakly defined. Preanal margin weakly concave in basal portion.

Postanal margin with 8-11groups of denticles, distal denticle in each group sharp, slender, much thicker and longer than others. Length of longest denticles little less than width of base of postabdominal claw. Postanal portion with 7-9 broad lateral fascicles of very short setules. Postabdominal claw (Fig. 2L) robust, irregularly curved, relatively short, shorter than preanal portion of postabdomen, with two basal spines, distal spine long, about 1/3 length of the claw, proximal spine two times shorter.
Antennule (Fig. 1G) of moderate size, length abouth 2 widths. Antennular seta thin, as long as antennule itself, arising at $1 / 3$ antennule length from the base. Nine terminal aestetascs of less than 1/2 length of antennule.

Antenna relatively short (Fig. 1H). Antennal formula, setae $0-0-3 / 1-1-3$, spines 1-0-1/0-0-1. Basal segment robust, with very short short seta between branches. Branches relatively short, in both branches basal segment two times longer and thicker than two others. Seta arising from basal segment of endopodite thin, a little longer than the endopodite. Seta arising from the middle segment of the endopodite of similar size than the apical setae. Spine on the basal segment of exopodite short, about $1 / 3$ length of middle segment. Spines on apical segments short, about $1 / 3$ length of apical segments.

Limb I of moderate size (Fig. 4A-B). Epipodite oval, without projection. Accessory seta short. ODL with two setae. IDL with three setae and several clusters of hard setules. IDL seta 1 of moderate size, about $1 / 3$ length of longest ODL seta, IDL setae 2 and 3 of similar size, with thin setules in distal part, slightly shorter than longest ODL seta. Endite 3 with four setae subequal in length, inner seta (1) is much thinner than outer setae $(\mathrm{a}-\mathrm{c})$. Endite 2 with two long distally setulated setae (e-f), a shorter seta near their base (d) and a naked inner seta (1) and small sensillum on anterior face of limb; seta e long, almost two times longer than seta $\mathrm{f}$ and almost as long as limb itself. Endite 1 with three 2-segmented setae of similar size $(\mathrm{g}-\mathrm{i})$, setulated in distal part, a flat plumose seta (j) and a naked inner seta (3) on the anterior face of the limb. Seven-eight rows of thin long setules on ventral face of limb. Two ejector hooks, one slightly shorter than the other. Maxillar process elongated, with short setulated seta in the distal part.

Limb II subtriangular (Fig. 4C-D). Exopodite elongated, of irregular shape, with seta 2 times longer than exopodite itself. Eight scraping spines with fine denticles, three basalmost spines subequal in length, others increasing in length distally. An inner seta located near the base of scraper 1. Distal armature of gnathobase with four elements. Filter plate II with eight setae, the posteriormost member shorter than others.

Limb III (Fig. 4E, 5A-B). Epipodite oval, without finger-like projection. Exopodite of ir- 

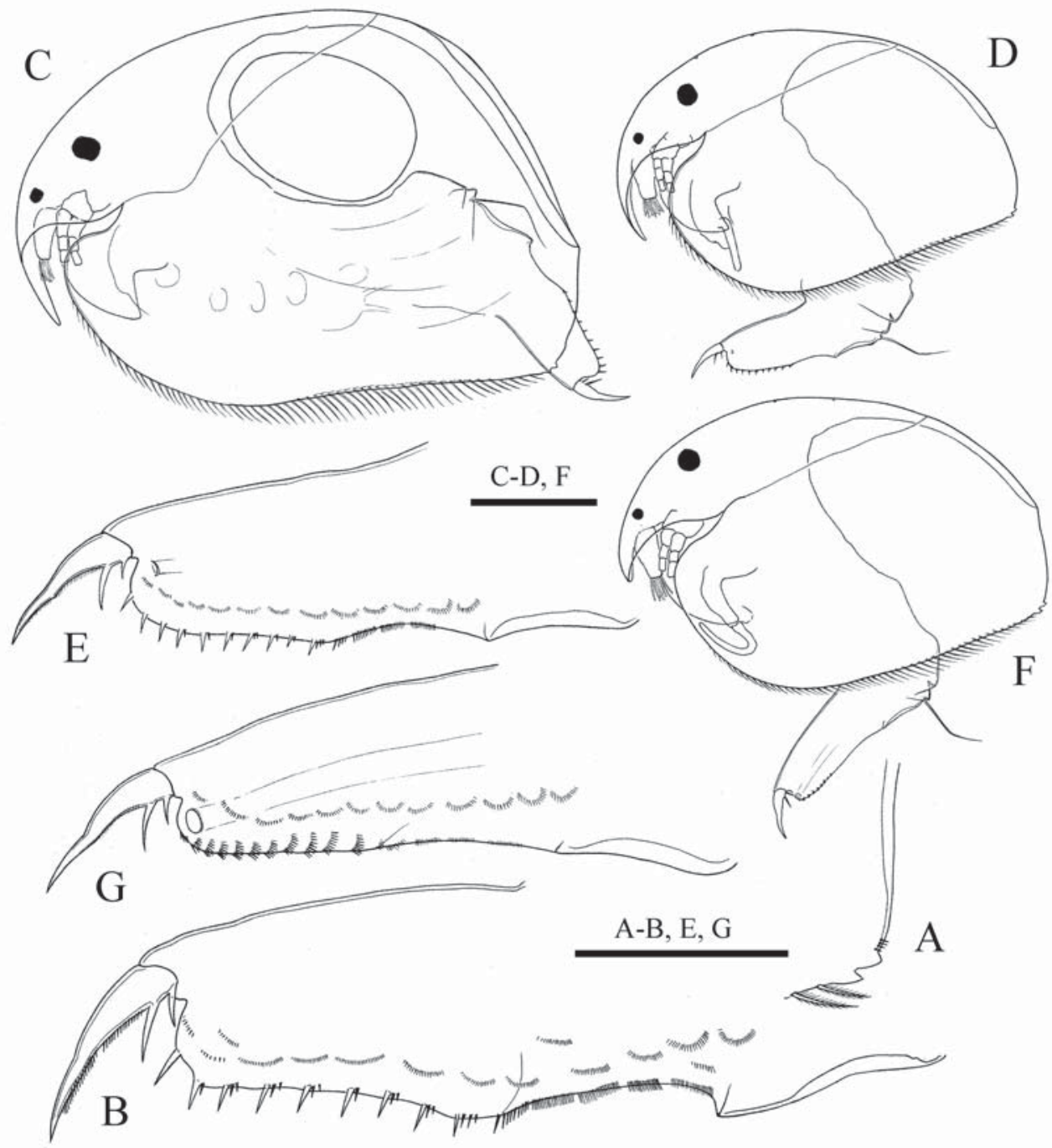

Fig. 3. Picripleuroxus quasidenticulatus (Smirnov, 1996) from Russia, Primorsky Area, Nakhodka District, Nakhodka, Primorskoe Lake.

A-B - parthenogenetic female; A - postero-ventral angle of valves; B - postabdomen; C - ephippial female; D$\mathrm{E}$ - juvenile male of instar II: D - lateral view; $\mathrm{E}$ - postabdomen; $\mathrm{F}-\mathrm{G}$ - adult male: $\mathrm{F}$ - lateral view; $\mathrm{G}$ postabdomen. Scale bars C-D, F-0.1 mm; A-B, E, G - $0.05 \mathrm{~mm}$.

Рис. 3. Picripleuroxus quasidenticulatus (Smirnov, 1996) из России, Приморский край, Находка, озеро Приморское.

A-B - партеногенетическая самка; А - задне-нижний угол створок; В - постабдомен; C - эфиппиальная самка; D-E - ювенильный самец второго возраста: D - внешний вид; Е - постабдомен; $\mathrm{F}-\mathrm{G}$ - взрослый самец: F — внешний вид; $\mathrm{G}$ - постабдомен. Масштаб: C-D, F - 0,1 мм; A-B, E, G-0,05 мм.

regular shape, with three lateral (1-3) and four terminal (4-7) setae. Seta 4 being longest, setae 5 and 6 subequal in length, about 3/43 length of seta 4 , seta 7 about $1 / 2$ length of seta 4 , setae $1-3$ of about $1 / 3$ length of seta 3 . Setae
1-5 plumose, seta 6 with rows of long setules in basal part and row of shorter setules in distal part, seta 7 with thin setules in distal part. Distal endite with 2 scraping setae (1-2), slender, sharp, with small denticles in distal part, 


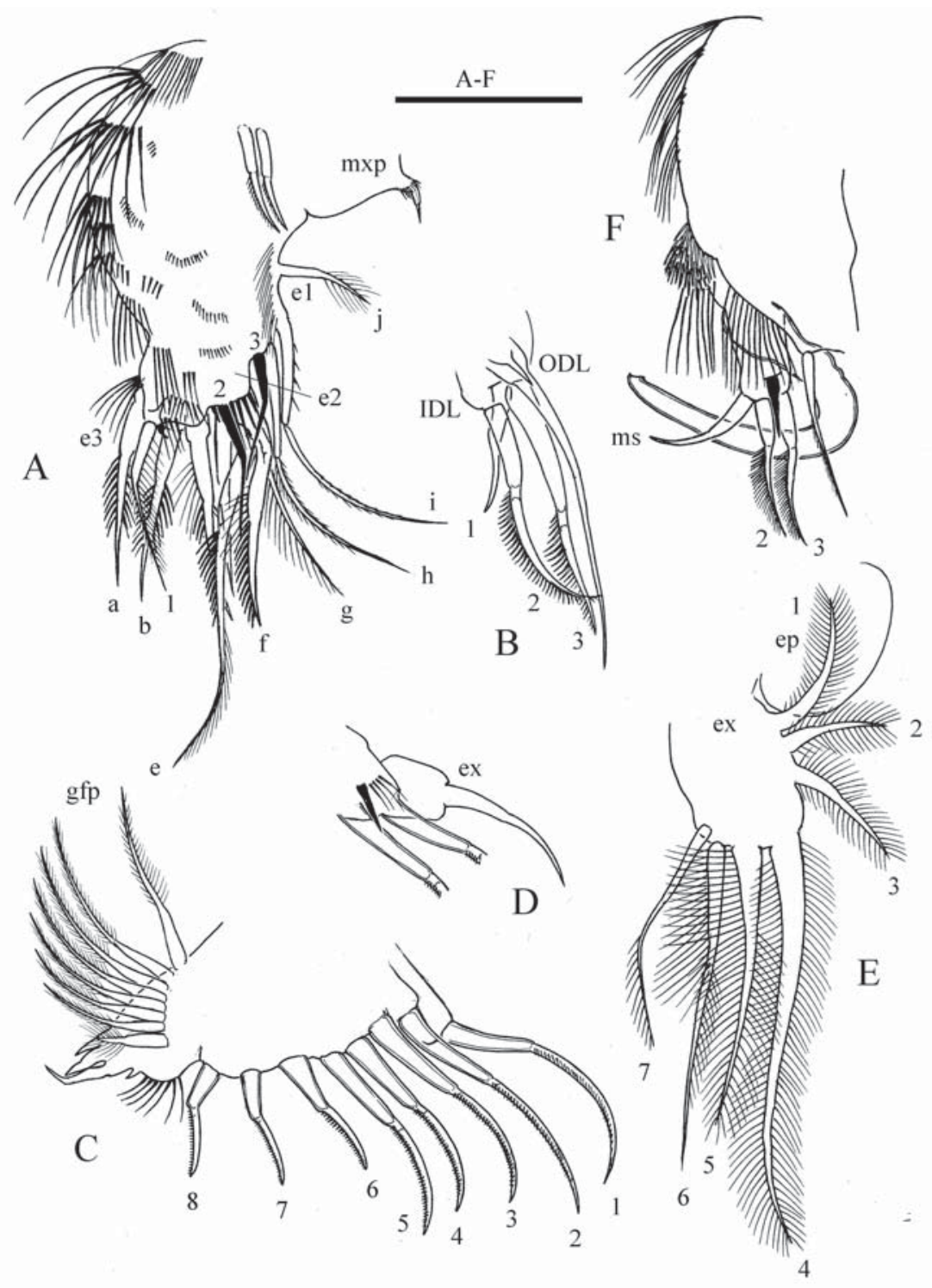

Fig. 4. Picripleuroxus quasidenticulatus (Smirnov, 1996) from Thailand, Khon Kaen area, Loeng Yai reservoir.

A-E - parthenogenetic female: A-B - thoracic limb I and its inner and outer distal lobes; C-D - thoracic limb II and its exopodite; E - exopodite of thoracic limb III; F — thoracic limb I of adult male. Abbreviations: e1-e3 - endites 1-3 of limb I; ex — exopodite; ep — epipodite; IDL — inner distal lobe of limb I; gfp — gnathobase filter plate; ODL inner distal lobe of limb I; ms - male seta; mxp - maxillar process of limb I. Scale bar $0.05 \mathrm{~mm}$.

Рис. 4. Picripleuroxus quasidenticulatus (Smirnov, 1996) из Таиланда, окрестности Кхон Кена, водохранилище Loeng Yai.

A-E - партеногенетическая самка: A-B - торакопод I и его внешняя и внутренняя дистальные доли; C-D торакопод II и его экзоподит; Е - экзоподит торакопода III; F - торакопод I взрослого самца. Обозначения: e1e3 - эндиты 1-3 торакопода I; ex - экзоподит; ер - эпиподит; IDL — внутренняя дистальная доля торакопода I; gfp — фильтрационный веер гнатобазы; ODL - внешняя дистальная доля I; ms - самцовая щетинка; mxp максиллярный вырост торакопода I. Масштаб 0,05 мм. 
two small sensillae located near their bases. Basal endite with 6 plumose setae $(a-f)$ increasing in size basally. Four pointed inner setae increasing in size basally, a small bottleshaped sensillum near the distalmost seta. Distal armature of gnathobase with four elements. The first one elongated, narrowing distally sensillum, second strongly geniculated seta, third and fourth - spines with fused bases. Filter plate III with eight setae.

Limb IV (Fig. 5C-E). Pre-epipodite setulated; epipodite oval, without projection. Exopodite rounded, with seven setae, length of setae decreases from seta 1 to seta 7 . Setae $1-5$ flat, plumose, seta 6 setulated unilaterally with short setules, seta 7 thin, geniculated. Inner portion of limb IV with four setae. Scraping seta (1) slender, three flaming-torch long and slender, decreasing in size basally, with 8-9 long setules each, small sensillum located near base of each flaming-torch seta.Four inner setae (a-d) slightly increasing in size basally. Gnathobase with one 2 -segmented setae, a small hillock distally and a sensillum. Filter plate IV with six setae.

Limb V (Fig. 5F). Pre-epipodite setulated; epipodite oval, without projection. Exopodite large, rounded, with four plumose setae, their length evenly decrease basally. Two small hillocks with long setules located on basal side of exopodite near seta 4 . Inner lobe long, narrow, with setulated inner margin. At inner face, two setae densely setulated in distal part, one of them two times longer than other, a small sensillum located between their bases. Filter plate $\mathrm{V}$ with four seta.

Ephippial female. Body of same proportions as in parthenogenetic female (Fig. 3C), ephippium intensive yellow-brown, without distinctive sculpture.

Adult male. Body (Fig 1H, 3F) moderately high, ovoid in lateral view, with maximum height at $1 / 3$ of the length, height/length ratio about 0.55 . Rostrum short and blunt, only little longer than antennule. Ocellus and eye same as in females.

Postabdomen (Fig. 1I, 3E) moderately long, narrowing distally, with maximum height at preanal angle. Length about 2.5 height. Spermoduct openings large, round, with row of setules along basal border, located laterally near the middle of the posterior margin. Ventral margin straight. Basis of the claws bordered from the distal margin by a weak incision. Distal margin weakly convex, distal angle broadly rounded, not prominent. Dorsal margin straight in postanal portion and weakly concave in anal margin, with distal part about 2.5 times longer than preanal margin, with postanal portion slightly longer than the anal portion. Preanal and postanal angles weakly defined. Preanal margin almost straight. Postanal margin (Fig. 2C) with 8 groups of short robust setules in place of female marginal denticles, lateral fascicles setules same as in female. Postabdominal claw (Fig. 2D) similar to that of female.

Antennule (Fig. 1J) broader than in female, with 9 terminal aesthetascs about half length of antennule. Male seta large, arising at the middle of antennule, about $2 / 3$ length of antennule.

Thoracic limb I (Fig. 4F) with U-shaped copulatory hook, half as long as limb itself. The IDL has four setae: IDL seta 1 two times smaller than in female, IDL setae 2 and 3 much thinner and two times shorter than in the female; the male seta curved, as long as seta 2. Ventral face of the limb with cluster of about 8 long setules under the copulatory brush, and with a row of about 10 long setules.

Juvenile male of instar II with body (Fig. 3D) of the same shape as in the adult male, postabdomen (Fig. 3E) similar in shape to that of the female, but with less prominent preanal angle, sperm ducts opens laterally, near the end of the postabdomen. Marginal denticles as in female.

Size. In females of second juvenile instar, length was $0.36-0.39 \mathrm{~mm}$, height $0.24-0.27$ $\mathrm{mm}$, in adult females length $0.43-0.51 \mathrm{~mm}$, height $0.30-0.38 \mathrm{~mm}$. Length of single studies juvenile male of instar II was $0.32 \mathrm{~mm}$, height $0.22 \mathrm{~mm}$, in adult male length $0.35-0.38 \mathrm{~mm}$, height $0.24-0.26 \mathrm{~mm}$.

Differential diagnosis. $P$. quasidenticulatus differs from closest species, $P$. denticulatus (1) by the absence of sculpture on the valves, (2) by the morphology of denticles on posteroventral corner of valves (in $P$. denticulatus denticles are longer, sharp, distance between denticles more than width of their base), (3) by the shorter postabdominal claw (in $P$. denticulatus length of claw is equal to length of preanal margin of postabdomen), (4) by the morphology of distal denticles on postabdomen (in $P$. denticulatus several distalmost denticles are clustered close together, same as in P. trigonellus 


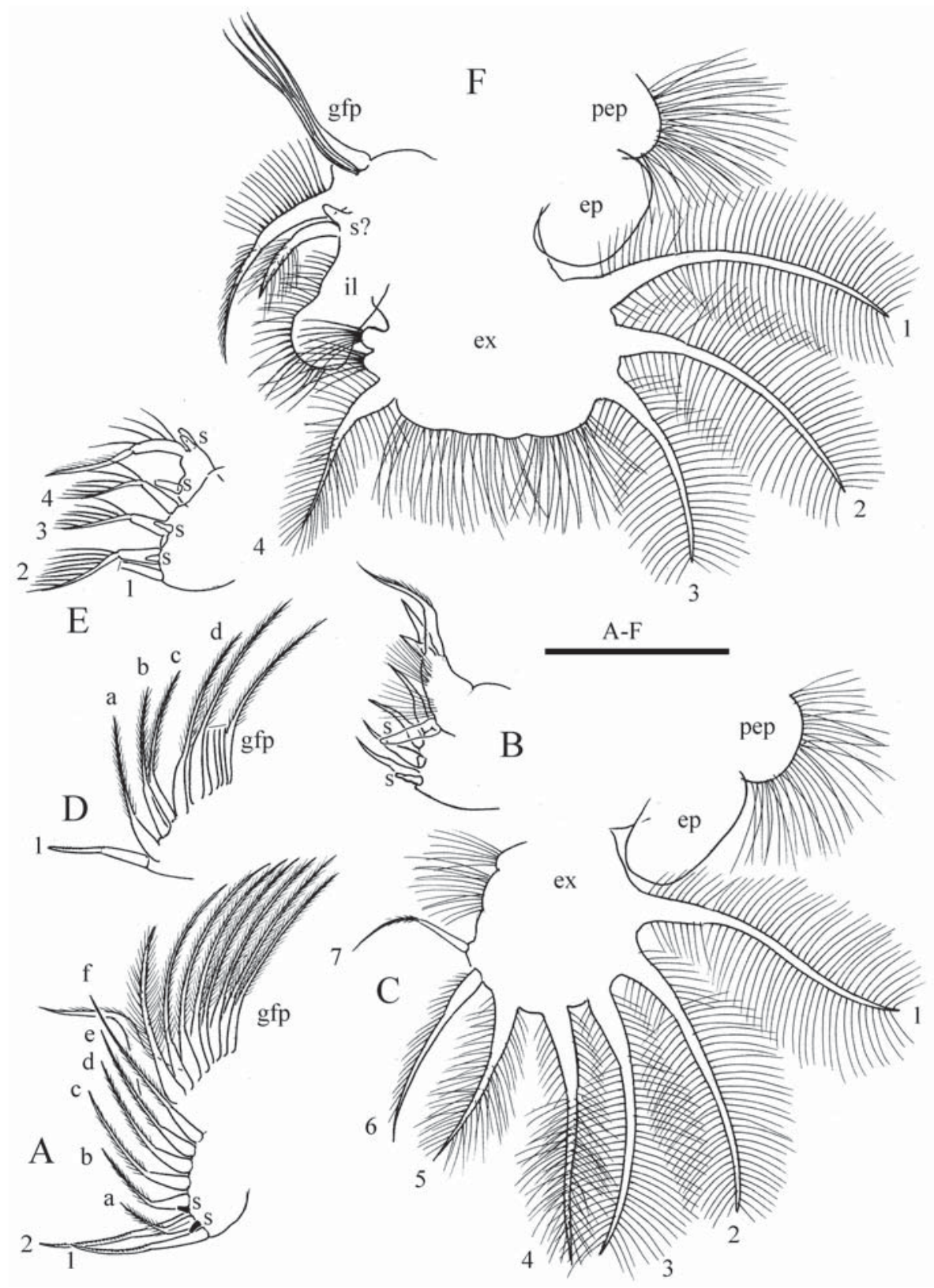

Fig. 5. Picripleuroxus quasidenticulatus (Smirnov, 1996) from Thailand, Khon Kaen area, Loeng Yai reservoir, parthenogenetic female.

A-B - inner portion of thoracic limb III; C - exopodite of thoracic limb IV; D-E - inner portion of thoracic limb IV; F — thoracic limb V. Abbreviations: ex — exopodite; ep — epipodite; il — inner lobe of limb V; gfp — gnathobase filter plate; pep - preepipodite; s - sensilla. Scale bar $0.05 \mathrm{~mm}$.

Рис. 5. Picripleuroxus quasidenticulatus (Smirnov, 1996) из Таиланда, окрестности Кхон Кена, водохранилище Loeng Yai, партеногенетическая самка.

A-B - внутренняя часть торакопода III; C - экзоподит торакопода IV; D-E - внутренняя часть торакопода IV; $\mathrm{F}$ - торакопод V. Обозначения: ex - экзоподит; ер - эпиподит; il — внутрення лопасть торакопода V; gfp фильтрационный веер гнатобазы; рер - преэпиподит; s - сенсилла. Масштаб 0,05 мм. 
(O.F. Müller, 1875). P. quasidenticulatus differs from the other species of subgenus Picripleuroxus, including coexisting $P$. sinkiankensis, by higher body, relatively wide postabdomen, and characteristic morphology of of denticles on postero-ventral corner of valve. For comparison between $P$. quasidenticulatus and $P$. sinkiankensis see Sinev, Korovchinsky (2013).

Ecology and distribution. This species is commonly found among macrophytes in the littoral zone of ponds and reservoirs; in Vietnam it was once found in a forest stream. For list of coexisting species from Thailand see Sinev, Sanoamuang (2011), from Vietnam Sinev, Korovchinsky (2013). Presently, the species is known from Australia and Iraq (Smirnov, 1996), China (Chiang, Du, 1979, listed as $P$. assimilis), Thailand, Vietnam, and Far East of Russia (our data), but probably has wider area of distribution.

\section{Discussion}

Our data confirms the validity of $P$. quasidenticulatus as a species. It differs from other species of the subgenus Picripleuroxus by female habitus, morphology of postabdomen and postero-ventral corner of valves. Males of $P$. quasidenticulatus differ from other species of the subgenus by the morphology of postabdomen. On the other hand, P. quasidenticulatus shares all features of the Picripleuroxus subgenus as proposed by Frey (1993).

We found no significant differences between populations of $P$. quasidenticulatus from Thailand, Vietnam and Far East of Russia. Records of $P$. denticulatus from India, according to Chatterjee et al. (2013) probably belong to $P$. quasidenticulatus. It is one of the few tropical species penetrating North as far as to the Far East of Russia. According to Korovchinsky (2013), only 7 out of 63 "good" tropical cladocera species recorded of Oriental region are penetrating North this far, and no such species were ever recorded among the Chydorinae.

The outer morphology of the specimens studied here is most similar to that reported by Smirnov (1996) for Iranian populations, and differs from that of the Australian populations in the shape of denticles of the postero-ventral corner of valves only. In Australian populations (see Smirnov, 1996, Fig. 79-95) variability of this character is higher, some specimens have more narrow and long denticles, not present in the Asian populations. The question of identity of Asian and Australian populations of $P$. quasidenticulatus is still open, and cannot be solved without a detailed revision of the Australian populations. At the moment, known differences are not enough to suggest the presence of sibling species in the Western Hemisphere. Many tropical species of Chydoridae are widely distributed in Africa, tropical Asia and Australia, or distributed in both Australia and Oriental region (see Korovchinsky, 2013). But sometimes, a revision of species-groups reveals that Australia and Oriental zone are inhabited by different sibling-species. In Alona pulchella-group A. pulchella (King, 1853) is known from Australia only, while its congener Alona cambouei inhabits tropical Asia, Africa and the Mediterranean region (Sinev, 2001), in the A. costata-group, A. setigera Breh, 1931 inhabits Australia, while A. cheni Sinev, 1999 is distributed from India to Southern China (Sinev, 2000). Other examples of such pattern are found among the Chydoridae.

Specimens identified as $P$. quasidenticulatus from Argentina (Smirnov, 1996: Fig. 108114), on the other hand, differ from the Old World populations in a longer postabdominal claw with a shorter basal spines. Denticles on the postero-ventral corner of the valves in South American populations are also more long and sharp, and have a regular row of spinules adjacent to (above) them, not irregularly spaced, as in Asian populations. We suggest that the South American populations of $P$. quasidenticulatus belong to a separate, yet undescribed species.

$P$. quasidenticulatus clearly differs from various American and European populations of $P$. denticulatus s.lat. (see Shan, Frey, 1983; Hudec, Illylová, 1998; Sinev, Zawsza, 2013) in the morphology of the postabdomen and denticles on the postero-ventral corner of valves, as well as in the sculpture of valves. But specimens of $P$. cf. denticulatus described by Chiambeng, Dumont (2004) from Cameroon are similar to $P$. quasidenticulatus in the morphology of the postabdominal claw, and while the morphology of postero-ventral denticles of the valves are somewhat different from that of $P$. quasidenticulatus, the resolution of the drawings is low and the differences are doubtful. These populations probably also belong to $P$. quasidenticulatus. 


\section{Acknowledgements}

Collection of the material from Vietnam was supported by and performed at the Joint Russian-Vietnamese Tropical Research and Test Center, South Division, Ho Chi Minh City. Special thanks to Anna B. Vasilieva and Nikolai A. Poyarkov for help during the sampling in Vietnam, Kay Van Damme and Henri J. Dumont for valuable comments on earlier draft. The study was supported by the Russian Foundation for Basic Research (grant \# 13-0401065-a for AYS), and was partly supported by the National Research University Project of Thailand, through the Holistic Watershed Management Cluster of Khon Kaen University.

\section{References}

Belyaeva M., Taylor D.J. 2008. Cryptic species within the Chydorus sphaericus species complex (Crustacea: Cladocera) revealed by molecular markers and sexual stage morphology // Mol. Phyl. Evol. Vol.50. P.534-546.

Chatterjee T., Kotov A.A., Van Damme K., Chandrasekhar S.V.A., Padhye S. 2013. An annotated checklist of the Cladocera (Crustacea: Branchiopoda) from India // Zootaxa. Vol.3667. P.1-89.

Chiambeng G.Y., Dumont H.J. 2004. The genus Pleuroxus Baird, 1843 (Crustacea: Anomopoda: Chydoridae) in Cameroon, Central-West Africa // Ann. Limnol. Vol.40. P.211-229.

Chiang S., Du N. 1979. [Fauna Sinica. Crustacea. Freshwater Cladocera]. Peking: Science Press, Academia Sinica. 297 p. [in Chinese].

Flössner D., Kraus K. 1977. On the variability and taxonomy of Pleuroxus denticulatus Birge(Cladocera: Chydoridae) // J. Fisher. Res. Board Can. Vol.34. P.463-476.

Frey D.G. 1985. A new species of the Chydorus sphaericus group (Cladocera, Chydoridae) from Western Montana // Int. Rev. Hydrobiol. Hydrogr. Vol.70. P.3-20.

Frey D.G. 1988. Separation of Pleuroxus laevis Sars, 1861 from two resembling species in North America: Pleuroxus straminius Birge, 1879 and Pleuroxus chiangi n. sp. (Cladocera: Chydoridae)// Can. J. Zool. Vol.66. P.2534-2563.

Frey D.G. 1993. Subdivision of the genus Pleuroxus (Anomopoda, Chydoridae) into subgenera worldwide // Hydrobiologia. Vol.262. P.133-144.

Frey D.G. 1995. Changing attitudes toward chydorid anomopods since 1769 // Hydrobiologia. Vol.307. P.43-55.

Hudec I., Illylová M. 1988. Pleuroxus denticulatus (Crustacea: Anomopoda: Chydoridae): a new invader in the Danube Basin // Hydrobiologia Vol.368. P.65-73.

Idris B.A.G. 1983. Freshwater zooplankton of Malaysia (Crustacea: Cladocera). Malaysia: Perenbit University, Pertanian. 153 p.

Kim K., Kotov A.A., Taylor D.J. 2006. Hormonal induction of undescribed males resolves cryptic species of cladocerans // Proc. R. Soc. London. Vol.273B. P.141-147.

Kotov A.A., Korovchinsky N.M., Sinev A.Y., Smirnov N.N. 2011. [Cladocera (Crustacea: Branchiopoda) of the Zeya River basin (Amurskaya area, Russian Fed- eration). 3. Systematic-faunistic and zoogeographic analysis] // Zool. Zhurn. Vol.90. P. 402-411 [in Russian, with English summary].

Kotov A.A., Sheveleva N.G. 2008. Separation of Pleuroxus pamirensis (Werestschagin, 1923) from P. annandalei (Daday, 1908) (Cladocera: Chydoridae) // Zootaxa. Vol.1775. P. 25-38.

Korovchinsky N.M. 2013. Cladocera (Crustacea: Branchiopoda) of South-East Asia: history of explorations, taxon richness and notes on zoogeography // J. Limnol., in press.

Kubersky E.S. 1977. Worldwide distribution and ecology of Alonopsis (Cladocera: Chydoridae) with a description of Alonopsis americana sp.nov // Int. Rev. Hydrobiol. Hydrograph. Vol.62. P.649-685.

Maiphae S., Pholpunthin P., Dumont H.J. 2008. Taxon richness and biogeography of the Cladocera (Crustacea: Ctenopoda, Anomopoda) of Thailand // Int. J. Limnol. Vol.44. P.33-43.

Shan R.K., Frey D.G. 1983. Pleuroxus denticulatus and $P$. procurvus (Cladocera, Chydoridae) in North America: distribution, experimental hybridization, and the possibility of natural hybridization // Can. J. Zool. Vol.61. P.1605-1617.

Sharma B.K., Michael R.G. 1987. Review of taxonomic studies on freshwater Cladocera from India with remarks on biogeography // Hydrobiologia. Vol.145. P.29-33.

Sinev A.Y. 2000. Alona costata Sars, 1862 versus related palaeotropical species: the first example of close relations between species with a different number of main head pores among Chydoridae (Crustacea: Anomopoda) // Arthropoda Selecta. Vol.8 (for 1999). No.3. P.131-148.

Sinev A.Y. 2001. Separation of Alona cambouei Guerne \& Richard, 1893 from Alona pulchella King, 1853 (Branchiopoda, Anomopoda, Chydoridae) // Arthropoda Selecta. Vol.10. No.1. P.5-18.

Sinev A.Y., Korovchinsky N.M. 2013. Cladocera (Crustacea: Branchiopoda) of Cat Tien National Park, South Vietnam // J. Limnol., in press.

Sinev A.Y., Sanoamuang L. 2011. Hormonal induction of males as a method for studying tropical cladocerans: description of males of four chydorid species (Cladocera: Anomopoda: Chydoridae)//Zootaxa. Vol.2826. P.45-56.

Sinev A.Y., Zawisza E. 2013. Comments on cladocerans of crater lakes of the Nevado de Toluca Volcano (Central Mexico), with the description of a new species, Alona manueli sp. n // Zootaxa. Vol.3647. P.390-400.

Smirnov N.N. 1971. [Chydoridae of the world] // Fauna SSSR. Rakoobraznie. Vol.1. No.2. Leningrad: Nauka Publ. 531 p. [in Russian]

Smirnov N.N. 1996. Cladocera: the Chydorinae and Sayciinae (Chydoridae) of the world. Guides to the identification of the microivertebrates of the Continental Waters of the world 11. Amsterdam: SPB Academic Publishing. 197 p.

Smirnov N.N., Kotov A.A., Coronel J. 2006. Partial revision of the aduncus-like species of Pleuroxus Baird, 1843 (Chydoridae, Cladocera) from the southern hemisphere with comments of subgeneric differentiation within the genus // J. Nat. Hist. Vol.40. P.1617-1639. E.N. Temereva, K.G. Mikhailov 